\title{
Impact of Asylum on Receiving Countries
}

\author{
Susan F. Martin, ${ }^{1}$ Andrew I. Schoenholtz ${ }^{2}$ \\ and David Fisher ${ }^{3}$
}

March 2003

\begin{abstract}
Whereas asylum seekers and the systems for adjudicating their claims to refugee status in developed countries have garnished considerable attention and, often, have been at the centre of political controversy, there has been relatively little research on their actual impact on receiving countries. This article discusses the factors that determine the impact of asylum, as distinct from other forms of migration, concluding that the number of asylum seekers, government policies and socioeconomic characteristics all determine the impact of asylum. Hence, the impacts of asylum can differ significantly from country to country. Even within the same country, one could expect to see varied impacts depending on the age, education and skill level of individual asylum seekers. The paper then examines the fiscal, economic, and social impacts of asylum, as well as its impact on foreign policy and national security. It concludes with an examination of the impact of developed countries' asylum policies on the protection of refugees in developing countries. When refugee protection has been weakened in economically strong states and asylum restrictions are perceived as burden shifting, international protection in the developing world where most refugees try to survive has been undercut.
\end{abstract}

Keywords: asylum, fiscal impact, economic impact, national security

JEL classification: F22, H50

\section{Copyright $(\subset)$ UNU/WIDER 2003}

1,2 Institute for the Study of International Migration, Georgetown University, USA; 3 Office of the High Commissioner for Human Rights, Switzerland

This study was prepared for the UNU/WIDER project on Refugees, International Migration and Poverty which is co-directed by George Borjas, Harvard University and Jeff Crisp, UNHCR. It was presented at the UNU/WIDER development conference on 'Poverty, International Migration and Asylum' held on 2728 September 2002 in Helsinki, Finland.

UNU/WIDER gratefully acknowledges the financial contributions to its 2002-2003 research programme by the governments of Denmark, Finland, Norway and Sweden. 
The World Institute for Development Economics Research (WIDER) was established by the United Nations University (UNU) as its first research and training centre and started work in Helsinki, Finland in 1985. The Institute undertakes applied research and policy analysis on structural changes affecting the developing and transitional economies, provides a forum for the advocacy of policies leading to robust, equitable and environmentally sustainable growth, and promotes capacity strengthening and training in the field of economic and social policy making. Work is carried out by staff researchers and visiting scholars in Helsinki and through networks of collaborating scholars and institutions around the world.

www.wider.unu.edu

$$
\text { publications@wider.unu.edu }
$$

UNU World Institute for Development Economics Research (UNU/WIDER)

Katajanokanlaituri 6 B, 00160 Helsinki, Finland

Camera-ready typescript prepared by Janis Vehmaan-Kreula at UNU/WIDER

Printed at UNU/WIDER, Helsinki

The views expressed in this publication are those of the author(s). Publication does not imply endorsement by the Institute or the United Nations University, nor by the programme/project sponsors, of any of the views expressed.

ISSN 1609-5774

ISBN 92-9190-430-9 (printed publication)

ISBN 92-9190-431-7 (internet publication) 


\section{Introduction}

The number of long-term international migrants (that is, those residing in foreign countries for more than one year) has grown steadily in the past four decades. According to the UN Population Division, in 1965, only 75 million persons fit the definition, rising to 84 million by 1975 and 105 million by 1985 . There were an estimated 120 million international migrants in 1990. As of 2002, according to the UN Population Division, there are 175 million international migrants (UNPD 2002).

Between 1965 and 1975, the growth in international migration (1.16 per cent per year) did not keep pace with the growth in global population (2.04 per cent per year). However, overall population growth began to decline in the 1980s while international migration continued to increase significantly. During the period from 1985 to 1990, global population growth increased by about 1.7 per cent per year, whereas the total population of international migrants increased by 2.59 per cent per year (IOM 2000).

The industrialized countries belonging to the Organisation for Economic Co-operation and Development (OECD) experienced significant growth in their immigrant population during the 1990s. In 1986/87, about 36 million international migrants (some of whom subsequently naturalized) lived in the US, France, Germany, Canada, Australia and the UK (OECD 2001). As of 2000, more than 63 million international migrants were reported to be living in these same countries, a 75 per cent increase (UNPD 2002).

These international migrants include both voluntary and forced migrants. Whereas international migration overall has shown a steady increase in the industrialized countries, the number of asylum seekers has ebbed and flowed over the course of the past two decades. According to the UN High Commissioner for Refugees, asylum applications showed a progressive increase during the 1980s (beginning with less than 200,000 in 1980), reached a peak in 1992, with almost 900,000 applications in the industrialized countries, then saw a reduction to less than 415,000 in 1997 , and a subsequent increase to more than 600,000 in 2001 (UNHCR 2001, 2002). The pattern varied by country, however. Germany saw a relatively steady decline during the latter part of the 1990s, from more than 400,000 in 1992 to about 90,000 in 2002, whereas the UK experienced a steady increase during this period, from a little more than 32,000 in 1992 to almost 100,000 in 2000 (UNHCR 2002). These fluctuations are explained, at least in part, by the origins of the asylum seekers. Germany was the principal destination of asylum seekers from the former Yugoslavia, and hence experienced significant inflows during the height of the conflict in Bosnia and subsequent declines after the Dayton Peace Accord. Government policies also affect flows, as do the assumptions made by smuggling and trafficking groups about vulnerabilities in migration control in individual countries.

Whereas asylum seekers and the systems for adjudicating their claims to refugee status in developed countries have garnished considerable attention and, often, have been at the centre of political controversy, there has been relatively little research on their actual impact on receiving countries. Many studies do not seek to distinguish between asylum seekers and other types of migrants. Other studies examine legal changes in asylum policies rather than the impact of asylum seekers and those granted asylum. Still others focus on specific nationalities, but even when the nationality is closely associated with 
asylum, the statistics do not permit an analysis of the experiences and impact of those who come through the asylum system versus other migration routes.

Given the paucity of research and data that can be used in assessing the impact of asylum on receiving countries, this article does not attempt to address the question through extensive empirical analysis. Rather, the next section discusses the factors that determine whether asylum, as distinct from other forms of migration, is likely to have specific enough impacts to be worth assessing on its own. The following sections summarize the research that exists on the impact of asylum and attempts to tease out of research on international migration more generally what the potential effects of asylum seekers are likely to be.

\section{Factors influencing the impact of asylum}

The impact of asylum, as distinct from other forms of migration, will be greater in those countries in which asylum accounts for a higher share of migration. There is considerable variation from country to country in the proportion of total international migration attributable to asylum seekers. In the US, for example, asylum applicants account for a small portion of the total number of new arrivals. Asylum applications averaged about 60,000 cases per year from 1997-2001, accounting for perhaps 87,000 persons (assuming 1.45 applicants per case), whereas most experts estimate that the number of long-term foreign residents increased by more than one million persons per year (counting both legal immigrants and unauthorized migrants who remain in the country for more than one year) (UNHCR 2002). Asylum has also been a small part of other humanitarian movements to the US; refugee resettlement and temporary protected status for victims of conflict and natural disasters represent far larger numbers (INS 2003: Table 4). By contrast, in many European countries, asylum applicants are 25 per cent or more of the annual inflow of international migrants (OECD 2001).

The impact will also vary depending on the proportion of the total population who are international migrants. In the traditional immigration countries, the foreign born/foreign national population account for upwards of 10 per cent of the total population; among non-traditional states, this is the case in Sweden and Switzerland. By contrast, the foreign born/foreign national population in other countries is below four per cent (for example, the UK, Ireland, Italy, Netherlands and Spain) (OECD 2001). Even if asylum seekers account for a significant share of international migrants, they are unlikely to have significant demographic, labour market or other generalized impact on the society as a whole. Asylum seekers may, however, affect greatly the public opinion about immigration if they are perceived as a growing population, even if not yet a significant one in numerical terms.

Government policies for handling asylum affect the impact of asylum seekers. First, governments make choices as to the systems used for adjudicating applications. If there are complex procedures with multiple levels of appeal, the fiscal costs of implementing the asylum systems will be higher. At the same time, the system may benefit from greater protection of the rights of the asylum seekers from forced return to persecution. If the government detains asylum seekers during lengthy adjudications, the fiscal costs will also be higher than if asylum seekers are released into the community and find their own housing and support networks. On the other hand, it may be more difficult to 
deport rejected asylum seekers if they are released from detention, creating another type of impact. And, if the government provides housing stipends and otherwise assists the asylum seekers during adjudications, the costs can be as high as detention. By contrast, if the government grants work permits, the fiscal impact may be lower (and in fact may become a net benefit through tax revenues), but again, it may be more difficult to remove a working asylum seeker if his or her application is rejected, and the work permit may be an incentive for abuse of the asylum system. If the asylum seeker obtains asylum, however, the work experience during the application stage may enable longerterm economic integration that will benefit the receiving society.

Impacts will also vary by post-adjudication treatment of asylum applicants. In some countries, a high proportion of asylum seekers are granted asylum, as is the case in the US and Canada, whereas in other countries, the vast majority of asylum applicants are rejected. Some of those rejected for asylum are nevertheless eligible for complementary forms of protection, particularly if they cannot be returned to a country undergoing conflict. The fiscal, economic and other impacts of asylum will vary depending on the eligibility of those granted some type of status to work, reside permanently, become citizens, obtain access to public assistance, enrol in language and other training programmes, reunify with families, etc. Depending on the nature and effectiveness of some of these policies, those granted asylum or complementary protection may become quickly self-supporting or languish for lengthy periods of time on public assistance rolls.

Policies on return of rejected asylum seekers, as well as individuals granted temporary protection who are no longer in need of such protection, also profoundly influence the ways in which asylum affects receiving countries (as well as source countries, the topic of another paper). If governments find themselves unable or unwilling to repatriate rejected asylum seekers, the domestic impact of the asylum system will be more longreaching than if the asylum seekers return home. If they are returned too soon, however, particularly to a fragile post-conflict country, the policies may negatively affect not only the asylum seeker but the potential stability of the country of origin as well. Postconflict Central American countries, for example, asked the US to permit their nationals to remain in the US because their remittances were considered essential to the reconstruction of their home communities (Migration News 2001). By contrast, other post-conflict countries have encouraged early return of their diasporas to participate in elections and to help in reconstruction. In this respect, the policies of the source countries can be as influential as the policies of the receiving countries themselves in determining the impact of asylum on the destination countries.

The socio-economic and demographic characteristics of asylum seekers will further influence the impact of asylum on receiving countries. Impacts will vary depending on the age, marital status and family structure of the asylum seekers. A large number of unaccompanied minors requiring assistance from public authorities will pose greater fiscal costs than a large number of working age asylum seekers who hold jobs. Impacts will also differ based on the education and skill level of those applying for asylum. Education and skills affect not only employment patterns but also earnings and income, particularly for those granted asylum and/or work permits.

This analysis of the factors influencing asylum patterns and outcomes demonstrates that there is no single way in which the presence of asylum seekers will affect a receiving country. The number of asylum seekers, government policies and socioeconomic 
characteristics all determine the impacts of asylum. Hence, the impacts of asylum can differ significantly from country to country. Even within the same country, one could expect to see varied impacts depending on the age, education and skill level of individual asylum seekers.

\section{Fiscal impact of asylum}

The most readily measurable impact of asylum is the cost to taxpayers to maintain an asylum adjudication process and to detain and/or care for and maintain asylum seekers. Governments complain of these costs but relatively little documentation is available of the actual numbers. The most comprehensive study of fiscal impact is a 1995 study by the International Centre for Migration Policy Development (ICMPD) entitled 'Structure and Cost of the Asylum Systems in Seven European Countries' (Jandl 1995). Focusing on Austria, Denmark, Finland, Germany (partial data), Norway, Sweden and Switzerland, the study estimated that the total annual state costs, including both processing and care and maintenance, amounted to almost US $\$ 2.7$ billion (not counting Germany).

Care and maintenance costs accounted for 93 per cent of the total costs, according to the ICMPD study. These costs included the cost of reception centres established to house asylum seekers until (1) a decision was made on their case or, (2) if granted status, they moved into their own accommodations. They generally also included social assistance and health care. Total care and maintenance costs varied greatly by country, depending on the number and characteristics of asylum seekers and those granted some other form of protection. Average costs also varied, generally by the type and duration of aid. The duration was in turn dependent on the average processing time, the potential for those who were granted status to continue to remain in reception centres or otherwise receive assistance, work authorization and other similar factors.

The processing costs accounted for US\$167 million, or six per cent of total costs, the study showed. These costs included the funding of admissibility procedures (first instance and subsequent appeals), legal representation of asylum seekers, and return of rejected applicants. The proportion of costs attributable to processing varied by country, with Norway spending 13 per cent of its costs on processing and Denmark and Finland spending less than 3 per cent on these activities.

Because the study was conducted in 1994-5, the findings were skewed by the large number of persons from the former Yugoslavia who were granted temporary protection without going through an adjudication of an asylum application. Those granted temporary protection were generally eligible for the same benefits as native residents of the countries. Even in countries where they were eligible for work permits, unemployment remained high.

A more recent study of fiscal impact came out of the Swedish government. The Swedish government estimated the per capita costs of reception in 2001 at 214 SEK per day, which was significantly down from the 340 SEK figure cited in the ICMPD study for 1990/91 (Migrationsverket 2002). Measured costs included food and accommodation, health and medical care, education and other similar costs. Sweden received 23,515 
asylum seekers in 2001. Unfortunately, the study does not indicate average number of days that an applicant received reception services, nor the total cost to the government.

The UK costs for providing support to indigent asylum seekers was £536 million in $1999 / 2000$ fiscal year and $£ 747$ million in 2000/2001 (UK Home Office 2001). A separately published study projected future costs (UK Home Office 2002), taking into account cost savings projected from changes in government policies. With a shift to voucher payments for some of the assistance then provided by the Department of Social Security, the study projected a reduction in total costs to $£ 448$ million.

These studies demonstrate the extent to which fiscal costs vary according to government policies regarding both adjudications and care and maintenance. While there has not been a similar study of the costs of asylum in the US, one could posit a far different picture than these European studies show. Asylum seekers in the US are not eligible for any federally funded public assistance, except for emergency medical care. ${ }^{1}$ They are also not eligible for work permits, unless the government takes more than six months to adjudicate their applications (rare for more recent applicants). ${ }^{2}$ As a result, the cost to the federal taxpayer is minimal for the type of care and maintenance provided in Europe. However, the US detains a larger number of asylum seekers than is true in most other industrialized countries, particularly those who enter with fraudulent or missing documents. Used as a deterrence measure, detention costs have been large and growing. Further, the costs of care and maintenance for those at liberty may well be shifted to family members, community groups and local authorities. Alternatively, the asylum seekers are working illegally, presenting a still different type of impact - this time undermining the credibility of the immigration work restrictions. It is important to note, however, that asylum seekers constitute a small proportion of undocumented workers in the US.

The shift, or at least allocation, in costs from central to state and local authorities is a factor in a number of countries. Generally, central authorities are responsible for adjudicating asylum claims, in keeping with national law as well as international commitments. However, asylum seekers are often distributed around the country, with state or local authorities having responsibility for their care and maintenance. In Germany, for example, the states (Länder) have principal responsibility for the reception and care of asylum seekers and those granted temporary protection, as is the case in Austria, Switzerland and other federal states (Jandl 1995). Some national governments (for example, Sweden) compensate municipalities for some of the costs incurred on behalf of asylum seekers (Jandl 1995). Even when asylum seekers work and pay taxes, states and localities may still bear a disproportionately high share of the fiscal costs. US studies of the fiscal costs of immigration in general repeatedly show that tax revenues generally accrue to the federal government (particularly from payments into the social security pension system) whereas many of the costs of education, housing, and health care are felt at the state and local level (National Research Council 1997).

1 Asylum seekers are excluded from the class of non-citizens allowed access to such assistance by Title 8 of the United States Code $\S \S 1641-42$ (2002). Persons granted asylum are eligible for cash and medical assistance during the first eight months after being granted status.

2 Title 8 of the Code of Federal Regulations $\S 208.7$ (a) (2002). 
The studies on the fiscal impact of asylum adjudications generally focus on gross expenditures, not taking into account possible contributions of asylum seekers and asylees to tax revenues. Work conducted in the US and the UK on overall fiscal impacts of migrants suggest that such an equation for asylum seekers and asylees would vary substantially, based largely on government policies regarding work authorization and the demographic and socio-economic characteristics of the asylum seekers. Younger immigrants with relatively high levels of education tend to be net contributors during the course of their lifetime, whereas older, less educated immigrants tend to remain a public cost (Gott and Johnston 2002; National Research Council 1997).

ICMPD has compared the costs of adjudication and care and maintenance for asylum seekers with the contributions of industrialized countries towards assistance and protection for the far larger number of refugees in developing countries. In 1993, for example, ICMPD estimated the total cost of asylum systems in 13 OECD countries to amount to US\$11.6 billion, whereas those same states contributed only US\$670 million to the UN High Commissioner for Refugees (Jandl 1995). Clearly, the cost of caring for refugees in highly industrialized countries exceeds greatly the cost of maintaining refugee camps in developing countries. The implication is that states would spend more money on refugees overseas if they had fewer asylum seekers at home. However, government budgets are not necessarily fungible in that way. The costs at home are generally paid by ministries responsible for social security and social services, or by Ministries of Interior (formerly Justice Department, now Homeland Security, in the US case). By contrast, funding for UNHCR generally comes from ministries responsible for development aid or foreign affairs. The ability to shift funding from one stream and agency to another is often very limited in government budgets.

\section{Economic impact}

The impact of asylum on the broader economic life of a receiving country is affected by such factors as government policies regarding eligibility for employment and welfare benefits, the education and skills characteristics of the asylum seekers, and the capacity and willingness of labour markets to absorb new entrants. While there has been much study, particularly in the traditional immigration countries, of the economic integration and effects of new immigrants, the literature often does not distinguish among labour migrants, family migrants, asylum seekers and resettled refugees. In fact, most of the economic integration and impact research conducted in the US, Canada and Australia focus on resettled refugees, with little attention to the experiences of those entering through the asylum system.

Generally, the literature assumes that labour migrants will have better economic outcomes than asylum seekers and resettled refugees, with family migrants fitting in between the two other groups. Labour migrants are generally chosen because of their skills or come spontaneously because they know of employment. Hence, a higher proportion is assumed to be employed and wage earning. Empirical evidence often, but not inevitably, supports this contention (Blos et al. 1997; Borjas 1994; Fix and Passel 1994). Family migrants come to receiving countries through family and community networks that are often able to place the newcomers into employment as well. Moreover, many governments allow family reunification only in those cases in which the applicants have sufficient financial resources to support the newcomers. 
By contrast, refugees are more strongly motivated by the push factors of conflict and repression, even though they may choose to claim asylum in a particular country because of their networks or perceived economic opportunities. Successful applicants for asylum are not chosen for their skills or family connections, but rather they are granted refugee or complementary status based on their well-founded fear of persecution or conflict. Their education and employment in their home country may well have been disrupted by the very circumstances that make them deserving of humanitarian protection.

Government policies may also work against early engagement in employment. Asylum seekers are often barred from working, at least until they obtain asylum or a complementary status. They may be isolated in reception centres or detention centres during the application process, or they may be dispersed throughout the country in order to avoid excessive burden on a few communities that would otherwise likely receive the majority of asylum seekers. If the settlement sites are chosen for their remoteness, rather than the economic opportunities available, the refugees may well find it difficult to obtain jobs even when authorized to do so.

If asylum seekers and approved refugees are eligible for cash assistance and social benefits, as is true in many countries, there may be little incentive to seek employment even if eligible. When the refugees have few transferable skills, they may find it difficult to obtain jobs that pay as well as the welfare system. In many cases, refugee families are larger than the average receiving country's families, making it even more difficult to replace the income derived from welfare benefits with wages.

Over time, however, the problems experienced by refugees may be overcome, leading to higher employment and income than other immigrants with similar educational background. Borjas (1982) has pointed out that 'refugees face higher costs of return immigration than do economic immigrants, and therefore the former have greater incentives to adapt rapidly to the US labor force'.

Empirical evidence appears to support this picture although there are too few studies of the economic situation of those entering through the asylum system to state the case definitively. A study of employment and wage assimilation of male first generation immigrants in Denmark showed that 'the initial employment probability of refugee immigrants is much lower than that of non-refugee immigrants'. Refugees from Africa and Palestine had lower rates of employment than those from Europe, Vietnam and the Americas. Refugees also started at much lower wage levels than non-refugee immigrants. Yet, after five to ten years in Denmark, 'the employment probability of refugees seems to approach the level of non-refugee immigrants and Danish born individuals'. With longer attachment to the labour market, the refugees would be able to close the wage gap as well, but it continued to be difficult for refugees to maintain full time employment over a ten-year period (Husted et al. 2000).

Brink (1997) found very high rates of unemployment for refugees in the Netherlands. She cites estimates from the Dutch Interdisciplinary Demographic Institute that more than 50 per cent of refugees in the Netherlands were unemployed, with more than 75 per cent of more recent arrivals (less than three years) without jobs. Her own small sample of refugees from the former Yugoslavia, Iran and Somalia also showed extremely low rates of employment (10 per cent) upon the grant of asylum (they were ineligible until the grant). Over the next 18 months, the employment rate grew to 30 per cent. The type 
of employment became more secure as well, with a majority holding contract jobs. Most of the unemployed refugees were following a course of Dutch language instruction. By the end of 18 months, only 2 per cent of the sample did not speak any Dutch (compared to 22 per cent at the beginning of the project). Some respondents also pursued vocational training programmes, generally at the recommendation of the employment services. Courses were sometimes at a lower level than the former work or educational experiences in the home country. If the refugees found jobs after vocational training, the employment was often at an even lower level of skill. It appeared that the human resources with which the refugees entered the Netherlands were not well utilized.

A study in the UK also found under-utilization of refugee skills. Bloch (1999) cites statistics from the Refugee Council that 70 per cent of refugees in London were unemployed in the early 1990s; a survey conducted by the Home Office at about the same time found that 56 per cent of the refugees had never been in paid employment and 30 per cent had only had sporadic employment in Britain. Factors influencing the dismal employment outcomes include lack of skills transferable to an urban environment, lack of English ability, lack of networks and personal ties to employers, lack of information about how to find a job, difficulty in providing references or evidence of former employment experience, and propensity for the refugees to see themselves as guests rather than long-term residents. Women refugees face particular barriers related to lack of skills, English ability and child care provisions.

Bloch surveyed 180 refugees and asylum seekers from Somalia, Sri Lanka and Zaire (Democratic Republic of Congo) who had been employed in a diverse range of jobs in their home countries. The refugee men held such jobs as teachers, engineers and shopkeepers, whereas the women had been working as cashiers, market traders and secretaries. Almost one-quarter had university degrees, and more than half had at least a secondary education. Only 16 per cent had only a primary education or no education at all. All of these were Somalis. At the time of the survey, however, only 14 per cent were working in Britain. Immigration status affected employment, with those already granted asylum or extraordinary leave to remain having higher rates than those with temporary permits or appealing a negative decision. Length of residence was also important in explaining employment, with a third of those who arrived in Britain before 1990 working but less than 10 per cent of those arriving in 1995 or later. The jobs were of a significantly lower skill level than the educational background of the refugees would indicate. The refugees cited such factors as racial discrimination and discrimination against refugees, along with their own lack of experience and English literacy skills, as major factors preventing them from getting a more suitable job.

Higher than average unemployment has also been found among refugees resettled in receiving countries. The likelihood of employment appears related to education, skills and government policies. According to Bach and Seguin (1986), Southeast Asian refugees in the 1980s were persistently 10-15 percentage points less likely to be in the labour force than the US population, and once in the labour force were likely to experience considerably higher levels of unemployment. Foreign education was the most significant predictor of labour force participation. Residence in California was also a strong predictor of unemployment, holding other factors constant, explained by the relatively more generous public assistance system in that state that permitted refugees to meet their household income needs through welfare rather than work. 
Hauff and Vaglum (1993) found a similarly poor labour force participation and unemployment experience among Vietnamese refugees in Norway. Unemployment was higher for refugees with low formal education. Wooden (1991) found that labour force participation rates among the largely Southeast Asian population of refugees in Australia were similar or higher than other immigrants, but their unemployment rates were much higher and they persisted over time. Although he cites discrimination against refugees and long-term 'scarring' arising from the initial high levels of unemployment as two possible reasons for the persistence in unemployment, Wooden emphasizes the importance of lower levels of English language skills as the more likely explanation of the poor labour market outcomes.

Even more highly educated resettled refugees find difficulties in adapting to the labour markets in their new countries. A comparison of Soviet Jews resettled in the US and Germany showed similar patterns of underemployment among refugees unable to transfer their academic and scientific credentials to new professional positions (Tress 1998). Krahn et al. (2000) found that refugees in Alberta who were in professions and managerial positions pre-resettlement experienced much higher rates of unemployment, part-time employment and temporary employment than do Canadian born individuals. Unfamiliarity with the Canadian job market, limited English skills, and controls over entry into professions in Canada (including certification and credentialing requirements) affect employment.

Given the high rates and, in some but not all cases, persistent pattern of unemployment among refugees, it is unlikely that they are having negative impact on the employment, wages or working conditions of other residents of the destination countries. Again, this is an area that has not been extensively researched. One of the few studies to examine this issue is Card's (1990) study of the impact of the Mariel boatlift on the labour market in Miami. He found that the Mariel Cubans increased the Miami labour force by seven per cent, and the unskilled labour force even more, but he found little negative effect on the wages or employment of lesser skilled workers, including Cubans who had migrated in earlier years. He pointed to the absorptive capacity of the Miami labour market that had repeatedly adjusted to the large waves of Cuban refugees. He did find, however, that the net migration of natives and other immigrants into Miami from elsewhere in the US slowed down after the boatlift.

Card's findings are at odds with most economic theory about the effects of immigration on employment and earnings. Generally, immigrants are believed to have a net positive impact on native populations who differ from them in education and skills, and a net negative impact on those with similar characteristics (National Research Council 1997). In other words, when immigrants are complements (rather than competitors) to the native population, the impact of immigration is largely beneficial. On the other hand, if immigrants are substitutes for the native population, or any part of it, the impact is negative for those who are in direct competition. In the US, to take an example, the educational level of the native-born population can be described as a diamond shape few Americans have less than a high school education and few Americans have more than a university education; most are in the middle. On the other hand, the educational level of the foreign-born population can be described as an hourglass - about 40 per cent of the immigrants have less than a high school education and more than 25 per cent have a university education or higher. Most immigrants are therefore complements to the US population. However, the foreign born are substitutes for those at the top and bottom of the educational ladder, where one might expect the greatest competition for 
jobs. Theory also dictates that immigrants will have the greatest impact on the immigrants already in the country since they are the most likely substitutes for their labour (National Research Council 1997).

To the extent that asylum seekers and refugees are complements to the prevailing population in destination countries, the impact of asylum should be beneficial, particularly if refugees are able to enter the workforce. On the other hand, asylum seekers may have negative impact on other immigrants if they arrive with similar educational and skill characteristics.

How the economic impacts will play out over time will be determined in large part by the receptivity of the receiving countries to integrating refugees into the labour market. In this regard, the demographic trends unfolding, particularly in Europe, may play an important role. In most developed countries, fertility levels are well below replacement rates - that is, couples are having fewer than two children (UN Population Division 2000). These countries can foresee a time in which total population will decrease, leading some demographers to refer to a looming population implosion. They can also expect an ageing population. According to United Nations Population Division projections, the number of persons aged 60 or older will increase from 600 million in the late 1990s to 2 billion in 2050 (UN Population Division 1999). The population of older persons will exceed that of children for the first time in history. At the same time, the number of working age persons per each older person will decline.

Some commentators already see refugees and asylum seekers as potential contributors to the economy if they are able to fill positions that would otherwise be unfilled. For example, a study conducted by the National Institute of Adult Continuing Education in the Leicester area of the UK concluded that about one-third of the asylum seekers in the vicinity had a higher education diploma and could help solve shortages in such areas as teaching, medicine and engineering (Aldridge and Waddington 2001). At the same time, an Assistant Commissioner in Scotland Yard recommended recruitment of refugees and asylum seekers as special constables who could work with ethnic communities, noting 'there are some real professionals [among] refugees and asylum-[seekers] ... They could do lots of roles - Special Constables, mediation, break down some of the bureaucracy, reduce criminality' (Bennetto 2001). Whether such sentiments proliferate as demographic pressures increase is still to be seen.

\section{Impact on social, cultural and community relations}

Asylum has been one of the most controversial migration issues facing many destination countries, affecting public perception of newcomers as well as social and community relations between asylum seekers and other residents. The controversy appears to have little relationship to the actual number of asylum seekers or their fiscal or economic impact on the receiving society. Rather, small numbers of asylum seekers even to such traditionally welcoming countries as Australia have precipitated extensive public backlash, often fuelled by political leaders who hope to benefit at the voting booths from a tough stance on unauthorized arrivals. On the other hand, very large groups of asylum seekers have been welcomed in receiving countries (Bosnians and Kosovars, for example), particularly when the situations they are fleeing are well known to the public and accepting them as refugees meets other priorities. 
Negative public reactions may derive as well from basic cultural and linguistic differences between the asylum seekers and already resident populations. There may be inter-group misunderstandings concerning practices that are viewed as offensive or upsetting by natives. In the US, community tensions tend to arise among minority groups, whereas, in Europe, the tensions appear to be strongest between the majority population and the newcomers (Christian and Martin 1999). The tensions are not generally related to asylum per se, but asylum seekers and refugees often come from countries whose traditions are far different from those found in the receiving society. For example, from the perspective of established residents, the presence of large, extended families in immigrant households produces overcrowded housing. In some cases, social and cultural practices of the newcomer groups, such as domestic violence, underage marriages, and female genital mutilation, are in violation of the laws of the host country.

Receiving countries have adopted a number of different strategies to address these community tensions. The most effective ones appear to fall into the following broad categories: promoting tolerance through educational programmes, empowering migrants to participate in civic affairs, orienting new immigrants to the communities in which they live, mediating conflicts, prosecuting offenses against racial and ethnic communities, establishing trust between migrant groups and law enforcement agencies, and reducing anti-immigrant discrimination. In addition to government efforts, nonprofit groups and faith-based organizations have been particularly active in educating the public about asylum seekers and educating asylum seekers about the laws and values of the destination countries.

\section{Impact on foreign relations and national security}

Asylum seekers - en masse or individually - can impact a state's foreign policy and national security. In the extreme, mass movements of those fleeing persecution or conflict can precipitate military intervention by a receiving country. Significant populations of asylees may play a major role in shaping a receiving country's foreign policy towards a sending country. With respect to individual security threats, asylum systems subject to abuse can impact national security.

Since the end of the Cold War, receiving states concerned about mass movements of asylum seekers have occasionally intervened in sending states in order to address the root causes of the movements. In 1994, the US removed a military regime and restored a democratically-elected President in Haiti in large part to quell the large number of Haitians who had taken to rafts and boats to escape the effects of repression in Haiti (Schwartz 2002). The US interdicted those who fled by boat and brought them to Guantanamo Naval Base as a safe haven. Interestingly, a similar exodus in 1992 following the overthrow of President Aristide resulted in a completely different foreign policy. In terms of foreign policy, the US government relied on diplomatic attempts to restore democracy in 1992, and interdicted and refouled asylum seekers rather than provide them with a safe haven.

A more serious threat to peace caused by ethnic warfare in the Federal Republic of Yugoslavia (FRY) resulted in a 78-day bombing campaign by the North Atlantic Treaty Organization (NATO). As of the beginning of the bombing on 24 March 1999, the 
Milosevic regime had already displaced some 260,000 Kosovar Albanians within Kosovo and an additional 200,000 in the rest of the FRY. Milosevic's forces then conducted a massive campaign of ethnic cleansing, uprooting nine-tenths of Kosovo's Albanians from their homes. Several factors precipitated the NATO intervention to stop an aggressive tyrant from further disrupting the Balkans, but among those factors was a concern that the repression of the Kosovar Albanians and its consequences would spread in the region (US Committee for Refugees 2000).

Ambassador Warren Zimmerman wrote about the spillover of asylum seekers as a threat to regional security in 1994 during the Bosnian civil war:

If, by accident or design, violence broke out in Kosovo, the historic area of Serbia 90 percent populated by Albanians, spillover could become a reality. Albanians could flee to Albania, already militantly anti-Serb, and to Macedonia, whose population is about 30 percent disgruntled Albanians. The moderate government of Macedonia could easily become destabilized, leaving the field to a match-up between the Albanians and the Macedonian nationalists who form a major political force in Macedonia. Interested neighbors could come into play: Serbia, which ruled Macedonia between the wars; Bulgaria, which has traditionally claimed that Macedonians are really Bulgarians; Greece, which has been waging a fierce economic war against Macedonia on the absurd assumption that Macedonia was threatening it; and Turkey, whose interest would derive from the involvement of its traditional enemy, Greece (Zimmerman 1995: 107-108).

Those granted asylum (asylees) may develop significant influence on a State's foreign policy once they make roots in the receiving country. The most salient case of this is the Cuban community in the US, particularly those in the Miami, Florida area. Once naturalized, these Cuban refugees exercised considerable power as a voting block during the Cold War. Even after the Cold War ended and the Cuban community developed differing perspectives on the appropriate foreign policy towards Castro's Cuba, the community remained influential in setting US policy.

Interestingly, that influence was seriously challenged in the summer of 1994 when 32,000 Cubans fled the island for south Florida. While some in the Cuban community had questions about the anti-Castro bona fides of those who took to rickety rafts and tires to escape, most wanted the US to continue to open its arms to these asylum seekers. In contrast with the US policy towards Haitian asylum seekers which was to interdict and return, or starting in the Spring of 1994 to interdict and provide safe haven at the Guantanamo Naval Base in Cuba, about 5,000 Cuban rafters had been picked up by the US Coast Guard and brought to the US during the first six months of 1994. That all changed on 19 August 1994. The Governor of Florida, Lawton Chiles, believed that perceived and actual impact of a mass influx on southern Florida communities would seriously erode his re-election bid that year. When the numbers of rafters significantly increased in August 1994, Governor Chiles informed President Clinton that he would declare a state of emergency to handle the situation himself if the President didn't take action to stop the influx. On 19 August, Clinton reversed a three-decade policy of welcome for Cubans seeking asylum in the US and announced that the Coast Guard would bring any rafters to Guantanamo where they would be held and screened. That interdiction policy continues today (Martin et al. 1998). 
Another important impact that those granted asylum or temporary protection may have on a State regards reconstruction and development aid or its equivalent to a sending country emerging from conflict. During the Bosnia civil war, for example, Germany provided temporary protection to some 350,000 Bosnians. Once the war ended in December 1995, the German government and certain of its states (Länder) with concentrated populations of Bosnians were anxious for the return of these refugees to Bosnia. Germany provided the civil war refugees with support for food, shelter, clothing, etc., and the fiscal impact of hosting this population was high on the minds of certain politicians. The timing of return was a major issue, as the country was devastated by the war, unemployment was very high, homes destroyed, about one million Bosnians were internally displaced, and communities ethnically cleansed and towns inhabited by new populations. The new Federation government wanted at some point to receive these predominantly Bosniak (Muslim) refugees from Germany, but urged the German government not to rush their return. The Bosnian Federation asked for reconstruction aid from Germany and the European Union in order to rebuild the country, resettle the internally displaced, and receive the returnees. Within the EU, Germany felt that it had spent considerable funds supporting the civil war refugees and that other European governments or the EU as a whole should shoulder the reconstruction burden. But individual German communities with Bosnian populations provided limited reconstruction aid and ultimately Germany responded along with the EU and several individual European governments at least partially to the significant reconstruction needs (Martin and Schoenholtz 1999).

The significance of remittances transmitted by civil war refugees has also played a key role in the foreign relations of certain governments. In the aftermath of conflict in Central America, Presidents of Central American countries such as El Salvador have asked the President of the US to allow the sending State's refugees to remain in the US so that they can continue to send remittances to help rebuild the war-torn country. Similar requests have followed natural disasters. In early 2001, following a major earthquake, the president of El Salvador met with President Bush with two requests. First and foremost, he asked that the US let Salvadorans stay and continue to send monies home. He also asked for some assistance to address the consequences of the natural disaster, but these monies were considerably less than the estimated US\$2 billion that Salvadorans in the US send back home every year (IADB 2002). For many reasons including pro-business and pro-immigrant values as well as a desire to attract Hispanic votes, President Bush granted both requests.

With regard to national security, two types of issues have arisen concerning asylum. First, on occasion, controversial political figures have presented receiving countries with both national security and foreign policy challenges when they sought asylum. The most recent example of this occurred in late 1998 when the leader of the Kurdish rebellion in Turkey, Abdullah Ocalan, requested asylum in Italy. Immediately after his arrest on warrants from Germany and Turkey, Ankara requested his extradition to stand trial on charges related to his activities as leader of the Kurdish Workers' Party (PKK), which was seeking independence for Turkish Kurds. The PKK urged Italy not to hand him over and threatened retaliation against Turkey. Ocalan's case presented Italy with a dilemma, squeezed between fellow NATO member Turkey's desire to try Ocalan and its own human rights positions and laws. Turkey charged that Ocalan was responsible for the deaths of 30,000 people over a 14-year period in his party's armed struggle for Kurdish autonomy. Human rights analysts estimate that 30,000 to 37,000 people have been killed on both sides of the conflict. Many Kurds consider Ocalan a freedom fighter 
and hero; however, human rights monitors have reported abuses committed under Ocalan's command. Italian law forbids extradition to countries with the death penalty, such as Turkey. Ocalan was on trial in absentia in Turkey on charges punishable with a death sentence: leading a terrorist organization, threatening the country's territorial integrity and ordering killings.

Italy refused to extradite Ocalan to Turkey, but Ocalan left Italy after an unsuccessful attempt to gain immediate asylum. The challenge became a wider-European one, as the Kurdish leader sought asylum in various European countries. Kurds in various European countries demonstrated and at times took violent actions to protest the treatment Ocalan received in Europe. European States were greatly concerned about the adverse impact that this asylum seeker would have on both foreign relations and national security. Reportedly Greece also refused to grant him asylum, but said that it provided him a place to stay in Kenya: 'The Greek Government, in order to seek help and find a solution to the problem of Abdullah Ocalan on a European level, granted him a place to stay in Kenya where he had travelled after his efforts to find permission to reside in various European countries'. The Greek Government denied that Ocalan had formally requested asylum but stated that he was not wanted in the country. "If he came to Greece, the Kurdish cause would become part of Greek-Turkish differences and that would be no good' (BBC 1999). The Kenyan authorities immediately arrested Ocalan and turned him over to Turkish authorities. In June, a Turkish court sentenced Ocalan to death. The death sentence has not been carried out.

A second type of impact on national security concerns the abuse of the asylum system by terrorists. The pre-eminent example of this occurred on 26 February 1993, when an explosive device exploded on the second level of the World Trade Center parking basement in New York City. The resulting blast produced a crater, approximately 150 feet in diameter and five floors deep, in the parking basement. The explosion killed six people and injured more than a thousand. More than 50,000 people were evacuated from the World Trade Center complex during the hours immediately following the blast. Six perpetrators of this attack were ultimately arrested, tried, convicted, and each sentenced to 240 years in prison. Two of the perpetrators had sought asylum in order to enter or remain in the US, including the mastermind, who entered the US with a fraudulent Iraqi passport, claiming asylum based on persecution in Iraq. His asylum application was still pending when the World Trade Center attack occurred. Evidence brought out at trial showed that the intent of the terrorists was to topple the city's tallest tower onto its twin, amid a cloud of cyanide gas. Had the attack gone as planned, tens of thousands of Americans would have died (Camarota 2002).

\section{Impact on international refugee protection}

The vast majority of refugees try to find protection and assistance in the developing world. According to the World Refugee Survey 2002, between 13 and 14 million of the almost 15 million refugees worldwide reside in Africa, the Middle East, and Asia. While only a limited number of refugees from these regions reach Europe, North America, or Australia, the asylum policies and practices in the developed world seriously affect the protection of the large numbers of refugees who remain in their regions. 
When states in the developed world violate the core protection obligation provided by the Refugee Convention and Protocol - non-refoulement - states in the developing world imitate their misbehaviour. During a two-year period from 1992 to 1994, the official policy of the US was to interdict Haitians on the high seas and return them directly to Haiti without considering any protection needs and rights they might have (Martin et al. 1998). This was a period of political repression in Haiti, as the democratically-elected government had been overthrown by a military coup. It was no surprise in 1996, then, when Côte d'Ivoire officials denied entry to a boat, the Bulk Challenge, carrying several thousand Liberian refugees. Despite a long tradition of generosity towards refugees from Liberia, Côte d'Ivoire did not hesitate to turn this boat away, knowing well that a key supporter of UNHCR had recently refouled thousands of Haitians on boats (US Committee for Refugees 1997).

Even when developed nations stop short of such open refoulement but deny entry to their territory, the message is clear: find protection elsewhere. Australia adopted a new policy to address boat arrivals of asylum seekers in late August 2001, not long before national elections were to be held. Under the new policy, Australia refuses to allow such arrivals into Australian territory and sends them to other countries in the Pacific, where their refugee claims are assessed. After the number of boat arrivals increased in the late summer, Australia refused entry to a Norwegian freighter, the Tampa, carrying some 430 persons, most of whom claimed to be Afghans. The Australians negotiated temporary refuge for the passengers with the tiny Pacific nation of Nauru and New Zealand. Australia provided Nauru with an aid package worth the equivalent of US\$10 million in return for hosting the asylum seekers. New Zealand said it would assess the asylum claims of those brought to its territory. The Nauru government asked UNHCR to screen the asylum seekers taken to Nauru, and UNHCR eventually agreed, but only for the group sent to Nauru. UNHCR expressed serious concern that Australia's actions could send a negative message to impoverished nations closer to conflict zones, which often take in hundreds of thousands of refugees (US Committee for Refugees 2002).

Roadblocks to asylum, in fact, have become the rule rather than the exception in developed countries during the last two decades. Visa requirements, carrier sanctions, safe country of origin and safe third country rules, expedited processing and removal, filing deadlines, detention, and pre-inspection discourage or bar asylum seekers from receiving protection in developed countries. Many analysts believe that such tools lead asylum seekers into the hands of smugglers, making escape and finding protection far more risky. Such roadblocks are being followed as well by countries just now developing individualized asylum systems. In fact, developed countries like Germany and the US have advised countries such as Poland and South Africa how to replicate the developed country asylum system. In some instances, these new asylum countries are taking further restrictive measures. In implementing its Refugee Act of 1998, for example, South Africa reportedly has limited the number of asylum applicants simply by refusing entrance to the office building where applications must be filed (US Committee for Refugees 2002).

Finally, it has become commonplace for the leading developed world nations to argue to developing countries that the South should act generously towards asylum seekers, at the same time that the North places significant restrictions in the way of those seeking asylum in the developed world. Given this contradictory approach, it is not surprising that the North's influence on international protection in the developing world has diminished. Developing countries with long traditions of generosity towards refugees, 
struggling to deal with continuing refugee crises in recent years, have chosen to follow what the North does as opposed to what it says.

Tanzania and Guinea, for example, have grown weary of large and continuous refugee influxes and are also increasingly concerned about security problems created by refugee warriors. Treatment of refugees after the passage of the 1998 Refugees Act became much more restrictive in Tanzania, for example, particularly with regard to freedom of movement. Analysts attribute this in part to the example set by the North. In fact, a perception exists that the North "is "shifting" rather than "sharing" the responsibility and burden of hosting refugees to those unfortunate enough to be located near refugeegenerating regions' (Kamanga 2002; US Committee for Refugees 2002).

\section{Conclusions}

To understand the impact of asylum on developed countries, it is first important to segregate asylum seekers from other types of migrants. The impact will vary depending on the proportion of the international migrants who are asylum seekers. While voluntary migration has generally risen steadily in the OECD countries over the last two decades, the movement of asylum seekers has come in ebbs and flows. The vast majority of migrants in the OECD countries are voluntary ones who migrate principally for employment or family reunification purposes. Of course, the proportion varies from country to country.

The impact will also vary depending on the proportion of the total resident population who are international migrants. Even in countries in which asylum seekers account for a significant share of international migrants, the total numbers in proportion to the native population are small. As a result, asylum seekers are unlikely to have significant demographic, labour market or other generalized impact on the society as a whole.

The most readily measurable impact of asylum is the cost to taxpayers to maintain an asylum adjudication process and to detain and/or care and maintain asylum seekers. Governments complain of these costs but relatively little documentation is available of the actual numbers. The limited studies available on the fiscal impact of asylum adjudications generally focus on gross expenditures, not taking into account possible contributions of asylum seekers and asylees to tax revenues and local economies. With regard to the latter, government policies regarding employment significantly affect the potential contributions of asylum seekers.

The economic impact of asylum turns on the government policies regarding eligibility for employment and welfare benefits, the education and skills characteristics of the asylum seekers, and the capacity and willingness of labour markets to absorb new entrants. Again, as the policies vary considerably among the OECD countries, the impacts also vary. To the extent that asylum seekers and refugees are complements to the prevailing population in destination countries, the impact of asylum should be beneficial, particularly if refugees are able to enter the workforce.

While asylum impacts social, cultural and community relations in a variety of ways, perhaps the most important concerns the tensions that arise over the newcomers. Interestingly, the tensions arise most in the US between newcomers and other 
minorities, while in Europe, the major friction occurs between newcomers and the majority population. Effective approaches addressing these tensions include: promoting tolerance through educational programmes, empowering migrants to participate in civic affairs, orienting new immigrants to the communities in which they live, mediating conflicts, prosecuting offenses against racial and ethnic communities, establishing trust between migrant groups and law enforcement agencies, and reducing anti-immigrant discrimination.

Asylum seekers have had important impacts on foreign policy and national security. States have intervened with force in order to prevent mass flows of refugees or address the human rights abuses that cause forced migration. When asylum seekers integrate into their host societies, they may exert considerable influence with regard to the host country's policies towards their country of origin. With respect to national security, asylum systems have been abused by terrorists who apply for asylum in order to enter or remain in their target country while their applications are pending.

Finally, the developed country's treatment of asylum seekers impacts the developing world's treatment of the vast numbers of such forced migrants. Refoulement in the North has been followed in the South. Restricting the entry and rights of asylum seekers in the developed world has been picked up and implemented in the developing world. When refugee protection has been weakened in economically strong States and asylum restrictions are perceived as burden shifting, international protection in the developing world where most refugees try to survive has been undercut.

\section{References}

Aldridge, F., and S. Waddington (2001). Asylum Seekers' Skills and Qualifications Audit Pilot Project. National Institute for Adult Continuing Education. Available at www.niace.org.uk/projects/Asylum/ Asylumreport.pdf.

Bach, R., and R. Carroll-Seguin (1986). 'Labor Force Participation, Household Composition and Sponsorship Among Southeast Asian Refugees'. International Migration Review, 20 (2): 381-404.

BBC (1999). Kurd Protests Sweep Europe, BBC News Online (17 February). Available at: news.bbc.co.uk/1/hi/world/europr/280355.stm.

Bennetto, J. (2001). Recruit Refugees to Scotland Yard, Says Police Chief. The Independent (25 June). Available at: www.unhcr.ch.

Bloch, A. (1999). 'Refugees in the Job Market: A Case of Unused Skills in the British Economy', in A. Bloch, and C. Levy (eds), Refugees, Citizenship and Social Policy in Europe. New York: Macmillan Press, 187-210.

Blos, M., P. Fischer, and T. Straubhaar (1997). 'The Impact of Migration Policy on the Labour Market Performance of Migrants: A Comparative Case Study'. New Community, 23 (4): 511-35.

Borjas, G. (1982). 'The Earnings of Male Hispanic Immigrants in the United States'. Industrial and Labor Relations Review, 35 (3): 343-53. 
Borjas, G. (1994). 'The Economics of Immigration'. Journal of Economic Literature, 32 (4): 1667-1717.

Brink, M. (1997). 'The Labour Market Integration of Refugees in the Netherlands', in P. Muss (ed.), Exclusion and Inclusion of Refugees in Contemporary Europe. Utrecht: European Research Center of Migration and Ethnic Relations, 187-203.

Camarota, S. (2002). The Open Door: How Militant Islamic Terrorists Entered and Remained in the United States, 1993-2001. Washington, DC: Center for Immigration Studies.

Card, D. (1990). 'The Impact of the Mariel Boatlift on the Miami Labor Market'. Industrial and Labor Relations Review, 43 (2): 245-57.

Christian, B., and S. Martin (1999). Transatlantic Perspectives on Improving Community Relations. Discussion Paper prepared for Transatlantic Learning Community: Migration Workgroup.

Fix, M., and J. Passel (1994). Immigration and Immigrants: Setting the Record Straight. Washington, DC: Urban Institute. Available at: www.urban.org/pubs/immig/ setting.pdf.

Gott, C., and K. Johnston (2002). The Migrant Population in the UK: Fiscal Effects. RDS Occasional Paper No. 77, London.

Hauff, E., and P. Vaglum (1993) 'Integration of Vietnamese Refugees into the Norwegian Labor Market: The Impact of War Trauma'. International Migration Review, 27 (2): 388-405.

Husted, L., H. S. Nielsen, M. Rosholm, and N. Smith (2000). 'Employment and Wage Assimilation of Male First Generation Immigrants in Denmark'. IZA Discussion Paper. Bonn: Institute for the Study of Labor.

IADB (2002). Remittances to Latin America and the Caribbean. Inter-American Development Bank, Multilateral Investment Fund

IOM (2000). World Migration Report 2000. Geneva: IOM and UN.

Jandl, M. (1995). Structure and Costs of the Asylum Systems in Seven European Countries. Vienna: ICPMD.

Kamanga, K. (2002). 'International Refugee Law in East Africa: An Evolving Regime'. Georgetown Journal, 3 (1): 25-35.

Krahn, Harvey, T. Derwing, M. Mulder, and L. Wilkinson (2000). 'Educated and Underemployed: Refugee Integration into the Canadian Labour Market'. Journal of International Migration and Integration, 1 (1): 59-84.

Martin, S., A. Schoenholtz, and D. W. Meyers (1998). 'Temporary Protection: Towards a New Regional and Domestic Framework'. Georgetown Immigration Law Journal, 12 (4): 543-87.

Martin, S., and A. Schoenholtz (1999). 'Temporary Protection: U.S. and European Responses to Mass Migration’. ISIM Working Paper, Washington, DC.

Migration Policy Group et al. (1996). The Comparative Approaches to Societal Integration Project. Brussels: Migration Policy Group. 
Migration News (2001). Latin America, 8 (3). Available at: http://migration.ucdavis.edu /mn/entireissues/mar_2001mn.html.

Migrationsverket (2002). Facts and Figures 2001 (Norrköping). Available at: www.migrationsverket.se.

National Research Council (1997). The New Americans: Economic, Demographic and Fiscal Effects of Immigration. Washington, DC: National Academy Press.

OECD (2001). Trends in International Migration: Continuous Reporting System on International Migration ('SOPEMI'). Paris: OECD.

Schwartz, E. (2002). 'Practicing at Home What We Preach Abroad: Lessons on Refugee Policy from the Clinton Administration'. Georgetown Journal, 3 (1): 13-23.

Tress, M. (1998). 'Welfare State Type, Labour Markets and Refugees: A Comparison of Jews from the Former Soviet Union'. Ethnic and Racial Studies, 21 (1): 116-38.

UK Home Office (2001). IND Annual Report 2000-2001. Available at: http://194.203.40.90/default.asp?PageId=1210.

UK Home Office (2002). Asylum Seeker Support - Estimates of Public Expenditure, London. Available at: www.homeoffice.gov.uk/rds/pdfs/asylummodell.pdf.

UNHCR (2001). Asylum Applications in Industrialized Countries: 1980-1999. UNHCR Population Data Unit, Population and Geographic Data Section. Available at: www.unhcr.ch.

UNHCR (2002). Number of Asylum Applications in 30 Industrialized Countries, 19922001. Available at: www.unhcr.ch.

US Committee for Refugees (1997). World Refugee Survey 1997.

US Committee for Refugees (2000). World Refugee Survey 2000.

US Committee for Refugees (2002). World Refugee Survey 2002.

US INS (2003). 2001 Statistical Yearbook. US Immigration and Naturalization Service, Office of Policy Planning.

UN Population Division (1999). Population Ageing 1999. UN Doc. No. ST/ESA/SER.A/179.

UN Population Division (2000). Replacement Migration: Is it a Solution to Declining and Ageing Populations? UN Doc. No. ST/ESA/P/WP/160.

UN Population Division (2002). 'Overview’. International Migration Report 2002.

Wooden, M. (1991). 'The Experience of Refugees in the Australian Labor Market'. International Migration Review, 25 (3): 514-35.

Zimmerman, W. (1995). 'Migrants and Refugees: A Threat to Security?', in M. Teitelbaum, and M. Weiner (eds), Threatened Peoples, Threatened Borders. New York: W.W. Norton \& Co., 88-116. 